\title{
WORKERS IN SOVIET MUSEUM \\ ETHNOGRAPHY IN THE 1950s: CLASS ANALYSIS AND POLITICS OF TIME
}

Keywords: Soviet ethnography, State Museum of Ethnography, Russian Museum of Ethnography, workers, class analysis, politics of time

\begin{abstract}
Drawn on archival materials produced by The State Museum of Ethnography of the Peoples of the USSR (nowadays The Russian Museum of Ethnography) in the 1950s, the article explores the ways in which the image of workers was constructed as an object of ethnographic inquiry and museum representation in the context of social and political changes that marked the period stretching from the late Stalinism to Khrushchev's "thaw". It focuses on the Russian workers seen as the largest and most significant "national group of the proletariat". Ethnographic studies of workers conducted during the period were conceptually based on the monolinear class analysis that was instrumental in establishing a temporal hierarchy separating the "advanced" working class from the "backward" peasantry. Yet, if in the early 1950s museum ethnographers tended to draw sharp lines between the workers and the peasants in their scholarly writings and exhibitions, the situation started to change with the coming of the Khrushchev "thaw" when class distinctions began to be blurred and ethnographers would constantly emphasize commonalities and similarities in the everyday life and culture of both groups.

This article is a translation of: Петряшин C.С. Рабочие в советской музейной этнографии 1950-х годов: классовый анализ и политика времени // Etnograficheskoe Obozrenie. 2021. No 4. P. 156-174. DOI: 10.31857/S086954150016707-7
\end{abstract}

There is in the Russian Museum of Ethnography ${ }^{1}$ in St. Petersburg in the 1980s and 1990s, a large exposition on the ethnography of the Russian people was built. Despite its advanced age, it is still open and represents primarily the traditional culture of Russian peasants at the turn of the XIX-XX centuries. Various peasant crafts are shown in the second hall of the exhibition, but one of the walls of the hall is devoted to the history and life of industrial workers. There are two skillfully executed models of the workshops of a weaving factory and a foundry of the late XIX century among the photographs, tools and other materials ${ }^{2}$. These ones show difficult working conditions and immerse the viewer in the atmosphere of factory life: women work 15-16 hours a day at closely spaced looms, they are helped by children; men

${ }^{1}$ It was founded in 1902 as the Ethnographic Department of the Russian Museum, since 1934 - the State Museum of Ethnography, since 1948 - the State Museum of Ethnography of the Peoples of the USSR, since 1992 - the Russian Museum of Ethnography.

Stanislav S. Petriashin | https://orcid.org/0000-0003-4410-7224| s-petryashin@yandex.ru | The Russian Museum of Ethnography (4/1 Inzhenernaya St., St. Petersburg, 191186, Russia)

Etnograficheskoe obozrenie. 2021. № 4. P. 313-328. https://doi.org/10.31857/S086954150016802-2

ISSN 0869-5415 (C) Russian Academy of Sciences (C) Institute of Ethnology and Anthropology RAS | http://journal.iea.ras.ru 
work in a gloomy dirty workshop filled with heat from a molten steel. Such pictures of working life are out of the general "positive" exposition narrative and seem like an unfit sample in an ethnographic museum specializing on traditional rural culture.

Now this part of the exhibition seems to be a strange and accidentally surviving relic. Nevertheless, It was in the 1950s part of a new ambitious project of Soviet ethnography to study the working class in the past and present. It was this time that the models describing life of Russian workers were made. Studies of everyday life of workers began in the late 1940s and were part of the post-war turn of Soviet ethnography to actual questions of modernity. A number of works are devoted to this turn, but all of them focus on the study of the life and culture of the collective farm peasantry as a main direction of ethnography of this time (Slezkine 1994; Abashin 2011; Haber 2014; Alymov 2010; Novozhilov 2012). The history of studying workers remains untold. The ethnography of contemporaneity ("new life", "socialist construction") of the 1920s and 1930s was also mainly engaged in rural residents (Hirsch 2005; Verniaev 2005; Petriashin 2018). It can be said that Soviet ethnographers of this time continued the romantic tradition of studying the rural population of European countries as a carrier of historical traditions and the "national spirit". The ethnography of workers, on the contrary, made a radical break with this tradition, since its object was the most "advanced" class of society from the point of view of the Soviet ideology. The Marxist "subject of history" and the collective sovereign of the Soviet "dictatorship of the proletariat" turned out to be on a par with the usual objects of colonization and ethnographic description as peasants and "exotic" natives. At the same time, when looking out of core of ethnography, workers were not a favorable object for research in comparison with a study of the Russian peasants, since the tasks, methods and scientific value of a study of the Russian working class were not clear.

This paper should answer the following questions. What were principles of a shaping of a working class as an object of study in a frame of the Soviet ethnography? How ideological models of class and national relations in the USSR were reflected in the ethnography of the workers and its research and representation practices?

Finally, how did the ethnography of the workers change under conditions of socio-political transformations of the 1950s? The main sources are archival and published materials of the State Museum of Ethnography of the Peoples of the USSR (the SME): scientific reports on expeditions, thematic and exposition plans, transcripts of discussions, guides to exhibitions and etc. The specifics of museum materials will allow to reveal the ethnography of the workers in two perspectives as academic research and museum representation. I focus on the Russian workers as the largest and most ideologically significant "national formation of the proletariat" in the USSR.

I consider a formation of the working class as a subject of ethnography in the context of the Soviet "politics of time". This concept was demonstrated by J. Fabian: "If it is true that Time belongs to the political economy of relations between individuals, classes, and nations, then the construction of anthropology's object through temporal concepts and devices is a political act; there is a "Politics of Time." "(Fabian 1983: X). According to Fabian, anthropological discourse is characterized by allochronism as placing the persons, which are subject of study, in a different time, as investigator regards them, with the help of temporalizing concepts as, for example, traditional and modern, peasant and industrial, rural and urban, etc. (Ibid.: 23). Anthropologists attributed modernity and development to Western societies, while other societies (often these ones are postcolonial) were considered to be backward and archaic. The ethnographic study of the peasantry in the Russian Empire and the USSR, as one of the tools of internal colonization, fits well into this model (Gouldner 1977-1978;

\footnotetext{
${ }^{2}$ The model of the foundry of the metallurgical plant was created based on the materials of the Rosenkrantz copper rolling plant in St. Petersburg (since 1922 - the Krasny Vyborzhets plant). The layout of the textile workshop was made according to the narratives of the older generation of workers in Ivanovo.
} 
Viola 1996; Etkind 2011; Etkind et al. 2012). Studies of industrial workers, however, require making adjustments to this one. The appearance of the workers as an object of researches at the turn of the 1940s and 1950s left only the Soviet intelligentsia out of the ethnographic focus in the position of an actor of this research. At the same time, subject-object allochronism between the intelligentsia and the workers was impossible due to the ideological importance of the proletariat. The Soviet working class, as the most progressive and playing a "leading role" in a society, could not be pushed by the intelligentsia into the "past" and in ideological terms rather embodied the "future in the present". As a result, the temporal hierarchy of the "advanced" working class and a lagging behind peasantry as two objects of the research has become constitutive for the ethnography of the workers.

In this sense, I consider the ethnography of workers as a product of a special type of a class analysis. In general terms, the history of a class analysis in the Soviet ethnography is known. It became the dominant method of research as a result of ethnographic summits of 1929 and 1932 and the forced "Marxization" of the discipline associated with these summits (Slezkine 1991; Hirsch 2005: 138-143; Solovey 1998; Arzyutov et al. 2014). Class analysis was actively used for the formation "diagnostics" of nations and the identification of class struggle in the past and present (Alymov 2014). In modern times, however, the class analysis was used mainly during collectivization. After the "great retreat" of the mid-1930s, when it was announced that socialism was being built in the USSR, the Marxist criticism of the Soviet state, and in some cases of the imperial past, became impossible out of ideological reasons (Timasheff 1946; Branderberger 2017). As a result, useful traditions and harmful "remnants of the past" have taken the place of antagonistic classes in ethnographic texts (Alymov 2014: 141-142; Baranov 2012: 351-366).

The attention of researchers of the Soviet ethnography, however, was attracted only by the classical Marxist type of the class analysis. Next, I call this multilinear. Within the framework of this analysis, antagonistic classes are identified, each of which has a specific historical experience, a special position in the present, a peculiar view of the past and the future (Morfino, Thomas 2018). At the same time, there are competing political projects and special temporalities behind the classes. Turning to the ethnography of the workers of the 1950s should help us to identify another type of class analysis, this is the monolinear one. This involves the identification of "friendly" classes in society, building a classless society and being in the same common time and political project. In this case, a temporal hierarchy is established between the classes in the form of a distinction between "advanced" and "lagging" classes. Nevertheless, they are moving together in the same direction of historical development as towards the future communism, as we approach this, class and national differences are come up. Each type of class analysis, identifying relations between social classes as specific temporalities turns out to be a special form of time (Ssorin-Chaikov 2017).

Since Soviet ethnography was defined as the science of peoples, the study of workers had to be somehow positioned relative to ethnic diversity and national politics. Let us return to Fabian again. As a postcolonial alternative to imperial allochronism, he proposed to discursively assert "coevalness", i.e. the radical contemporaneity of all societies, nations and classes, their coexistence in one time. The concept of coevalness is actively criticized for leveling the multiplicity of local histories and reproducing the dominance of the West and allochronism at another level (Chakrabarty 2000; Birth 2008; Beverage 2016) ${ }^{3}$. The study of the ethnography of the Soviet workers must show how the ideology of equality of peoples and the discourse of class allochronism interacted and supported each other.

In the perspective of this work Fabian's "coevalness" can be represented as an analogue of the postcolonial Soviet discourse of "friendship and brotherhood of nations", which

\footnotetext{
${ }^{3}$ This criticism is not entirely fair. According to Fabian, coevalness is not reduced to homogeneous time, but acts as a form of simultaneity of conflicting and contradictory forms of consciousness, dialectical confrontations between individuals and communities (Fabian 1983: 146, 154).
} 
implied the equality (or the process of "equalization") of the Soviet nationalities and the "synchronization" of their histories in the era of socialism. Ethnographers had to confirm this equality by examining in each nation its working class as a symbol of economic and cultural development. The achievements of agriculture as the collective-farm peasantry were of less value in the eyes of the Soviet government and could not serve as convincing proofs of the achieved equality of peoples. In this sense, the monolinear class analysis was manifested in the ethnography of the workers both in the form of class allochronism and in the form of the equality of peoples in the time of socialism ${ }^{4}$.

The first part of the article is devoted to the prehistory of the ethnography of workers and tells about the study and displays of class relations and industry in the SME of the 1930s. It is the second section there I consider the formation of the ethnography of workers at the turn of 1940s-1950s in the SME on the example of first expeditions and exhibition projects. The third part of the article wears analysis of changes in the principles of studying and exhibiting the culture and everyday life of the workers in the mid-1950s.

\section{Class analysis and Industry in Museum Ethnography of the 1930s}

The State Museum of Ethnography (nowadays - the Russian Museum of Ethnography) was founded in 1902 as the Ethnographic Department of the Russian Museum of Emperor Alexander III. Initially, there were four curators for its staff, but in the 1920s the museum was able to expand its staff and form four scientific departments: ethnography of Russians and Finns (I), ethnography of Ukraine and Belarus (II), ethnography of the Caucasus and Turkestan (III), ethnography of Siberia's nations and nations of the Far East (IV). The exposition of the museum of this period had a similar structure.

The theme of the class struggle and the corresponding multilinear class analysis became part of the museum's ethnographic exposition and academic text as a result of the "cultural revolution" of the turn of the 1920s and 1930s. According to the resolution of the First AllRussian Museum Congress of 1930, all museums had to rebuild their expositions on the Marxist grounds and turn to political and educational activity. The purpose of ethnographic museums was no longer to study and demonstrate the ethnic diversity of the country, but "to show the results of the national policy of the dictatorship of a proletariat, to show the destruction of the inequality of nationalities, the industrialization of backward areas and the flourishing of national cultures" (Milonov 1930: 4-5). At the same time, it was assumed that the successes of the Soviet government was based on the "class struggle" in the past and present, so this subject should have become one of the leading ones in museum work.

The expositions of the Ethnographic Department (since 1934 SME) in the 1930s were devoted, as a rule, to one nation or to a group of close nations within the framework of one Union's Republic. So, each major Soviet nation could count on a separate exhibition in the museum as the materialization of its specific culture and history. The unified structure of the expositions, the sections of which corresponded to socio-economic formations, was supposed to emphasize the interrelationships between peoples, their "equality" in the general time of Marxist evolutionism. The exposition on pre-revolutionary history in rare cases began with the primeval nature as exposition of archaeological materials; most often this was limited to feudalism and capitalism. Each exposition ended with a "Soviet" section, which is an overview of the socialist construction by a particular nation.

In the pre-revolutionary part of the exhibition, the display of standard ethnographic objects (occupations, housing, clothing, rituals, etc.) was politically sharpened and presented based on the perspective of class analysis and anti-colonialism. Imperial administrators and soldiers, local elites, "kulaks" (wealthy peasants) and clergy were shown as exploiters,

${ }^{4}$ Similarly, the multilinear class analysis determined the anti-colonial rhetoric, which since the mid-1930s had been applied only to the historical past of the USSR and foreign countries. 
and poor peasants and "inorodtsy " (non-Russian population of the empire) as exploited persons. For example, one of the panels at the exhibition "Peoples of the Sayan-Altai" (1932) was dedicated to the Russian peasant colonization ${ }^{5}$. Drawings, photographs and diagrams showed an increase in the number of "kulaks" in the region and the amount of land occupied by them. The text at the end summed up: "Russians are getting rich due to the exploitation of the local population."

The themes of the revolutions of 1905 and 1917, intervention and the Civil War served as a transition to the modern part of the exhibition. In the Soviet section, against the winning background of pre-revolutionary backwardness, materials were exhibited about the achievements of socialist construction (the prosperity and culture of collective farmers, the flourishing of national culture, etc.). The exhibitions of the early 1930s, while demonstrating contemporaneity, also showed the class struggle around collective farms. For example, in the exposition "Byelorussia and the BSSR" (1933) a single display case included two scenes: a "kulak", digging in a grain, and the milkmaid- saboteur, smearing inside cans by acid for a fast outsorting a milk (Supinsky 1934: 53-54).

For the collection of materials on socialist construction the expeditions were organized. Until the mid-1930s, field reports often included descriptions of the class struggle. For example, in 1934 V.S. Dubov wrote in a scientific report about a Karelian collective farm:

Kulak elements $<\ldots>$ pretending that they went out for logging are drinking for several days with their friends in another village, thereby undermining the plan of harvesting. The same elements are agitating among the collective farmers for not going to work, for religious holidays during summer field work, for leaving the fields not mowed $\langle\ldots\rangle$, for low rates of grain harvesting (ARME1: d. 481. 1. 7).

Museum ethnographers of the 1930s focused on the study and representation of rural life, but were not limited to it. I would like to say that the ethnography of the early 1950s was partly prepared by pre-war museum studies of industry. Class analysis in those studies, however, was also applied only in the early 1930s. There were practically no expeditions devoted entirely to the study of the industry. Plans of a field work, which usually lasted from two to six weeks, as a rule, had little time for a research of the industry, as usually from a few days to a week. The staff of the SME considered the study of the industry to be no priority for an ethnographic museum and more appropriate for the tasks of creation of local historical and political enlightenment exhibitions (Kryukova, Studenets-kaya 1971: 49). Accordingly, the material collected during the fieldwork was not reflected in scientific publications.

The geography of the expeditions was quite diverse. So, in Uzbekistan, M.V. Sazonova and Zh. Ia. Dekhterenko worked at the Shorsu sulfur mines and at textile mills in Tashkent and Margilan. N.P. Grinkova and N.A. Dyleva studied a sawmill in Arkhangelsk, and T.A. Kriukova studied a metallurgical plant in Lipetsk. It was in Ossetia there E. N. Studenetskaia studied Sadonian silver-lead mines (ARME2: d. 304. 1. 10).

A relatively large number of industrial studies were conducted for the exposition of the local history character "Karelia and the Kola Peninsula" (originally "Leningrad Region and Karelia”) (1935). So, in the autumn of 1932, Z.P. Kalinovskaia collected materials in Murmansk on the technique of industrial processing of fishing as a production of fish flour, medical fat, fish skins, export cod and etc. Exhibits were purchased as fish flour, medical fat, stearin, cod liver, production tools and etc. (Malinovskaya 1932: 233). For the characteristics of industry, ethnographers brought mainly photographs, newspapers, various statistical data and "production collections" as tools, industrial materials, production samples and etc., this lasted until the mid - 1930s in frame of the expeditions. To compensate for the uniformity of such materials, many interior scenes and models were created to show socialist construction in the industry. For example, at the exhibition "Karelia and the Kola

\footnotetext{
${ }^{5}$ RME photo library. ИМ 3-19.
} 
Peninsula", two sections devoted to geological exploration and development of apatite ore were presented side by side. According to the exhibition guide, "both the "Geological Exploration" stage with the latest electro-magnetic equipment, which allows detecting the presence of metal in the ground with the help of a radio receiver, and the drilling of apatite mountain by means of an air drill of a perforator, show the use of the latest technology in the area of activity in this previously a backward region" (ARME1: d. 496. 1. 19). The scenes were complemented by an exhibition of samples of minerals and products of the processing plant as apatite and nepheline concentrate.

As can be seen from this brief review, the class analysis was used by museum ethnographers only to characterize the pre-revolutionary life of peoples and their situation during collectivization and industrialization of the First five-year plan. In the second half of the 1930s the Soviet society was presented in the museum almost outside the paradigm of classes. The demonstration of the success of industry and agriculture in different republics of the USSR was supposed to demonstrate the development of previously backward territories and nations, the "leveling" of their standard of living in the time of socialism, the "bonding" of the city and the countryside, the destruction of the boundaries between classes. The study of industry in the SME of the 1930s mostly ignored the workers themselves, their way of life and culture. In other words, the task of ethnographic research of the working class was not yet been set.

\section{Ethnography of workers in 1950-1952: reproduction of class boundaries}

Before turning to the post-war museum ethnography of workers, it is necessary to briefly outline the historical context of the late 1940s. As a result of the industrialization of the 1930s "the former national suburbs of tsarist Russia turned from regions, which produced agricultural and raw materials, into republics with a highly developed industry" (Astapovich, Gusev 1962: 3). This was also facilitated by the Second World War, during which many enterprises were evacuated from the European part of the USSR to the Urals, Siberia and Central Asia. As a result, "national squads of the working class" appeared in big numbers (Mitrofanova 1964: 62). The political and ideological sphere had a more direct impact. In the second half of the 1940s in the wake of the campaign against cosmopolitanism, criticism of Soviet humanitarians for "lack of ideas and apoliticality" became tougher. Ethnographers and folklorists were also not left out of this political motion in the Soviet state (Alymov 2009). So, in the "Literary Gazette" in 1948 they were characterized as "specialists in lowworship", and their articles irritated critics with their "extreme scholasticism, strict isolation from the pressing issues of our time" (Butusov 1948: 3). Instead of studying the folklore of the Great Patriotic War, "new people and a new culture", ethnographers and folklorists studied traditional rituals and remnants of the primitive communal formation (Balakin 1948: 3). As negative examples, the articles of the SME staff about the South Russian rite of "driving a mermaid" (Grinkova 1947; Kryukova 1947) were also cited.

Reacting to the current dangerous situation, the leadership of the Institute of Ethnography of the Academy of Sciences decided that scientists had to study "the culture and life of modern peoples: socialist nations and nationalities of the USSR, modern bourgeois nations, nations of colonies and dependent countries" (Zhdanko 1951: 214). Already in 1948, the directorate instructed ethnographers to pay special attention in their fieldwork to the study of contemporaneity, in particular, collective farm life. The study of labor began at the turn of the 1949-1950-s. Six expeditions went to the plants of Moscow, Leningrad, the Urals, Ukraine and Bashkiria (Korbe 1950: 185). Soon, the geography of research was expanded, and ethnographers began to survey industrial enterprises in Uzbekistan, Kazakhstan and other Union republics. The inclusion of working life in the subject area of ethnography was fixed at the Ethnographic Meeting at the Institute of Ethnography, held in Moscow in 1951. The resolution was: "The central place in the work of Soviet ethnographers 
should be the study of the socialist life of the collective - farm peasantry and the working class of the USSR" (Resolution 1951: 231). The work of ethnographic museums also changed accordingly. Now they had to show national peculiarities on the material of the peasantry and the workers (Ibid.: 233).

The SME turned to the subject of the working class in 1950, following the Institute of Ethnography. The need to study and show workers in the Ethnographic Museum was explained by E.A. Milstein (director of the museum in 1937-1941 and 1944-1953; see about him: Dolgova 2018). In his report to the museum staff on the work plan of the SME for 1951-1955, he noted that the museum could no longer be content with showing only peasants, especially when demonstrating the Soviet contemporaneity. Many peoples before the revolution "did not have their own working cadres, their own intelligentsia and not to show them, this means to show the people one-sidedly, to distort the development of the people and its culture in the Soviet period and not to highlight the colossal achievements that each people achieved under Soviet conditions" (ARME1: 1046. L. 9). Accordingly "the further direction of the Museum's exposition activity should go along the line of showing the people, the nation, i.e. both collective farmers, workers, and intellectuals" (Ibid.: 1. 6). Looking ahead, it is worth saying that neither the study nor the display of the intelligentsia took place.

Already in these program provisions, Milstein identified the key aspects of the ethnography of workers. The display of the workers served as a means of demonstrating the equality of peoples in the era of socialism. But at the same time, a temporal hierarchy was built: the peasants were before and remained after the revolution, and only the workers (together with the intelligentsia) were among the "colossal achievements" of the Soviet period. Finally, the director appealed to ethnographic holism and spoke about the need to study each nation "as a whole", i.e. all its classes.

To show the working life, especially its current state, it was necessary to collect ethnographic materials in expeditions. Milstein also undertook the preparation of an ethnographic questionnaire for research of workers. By the field season of 1951 it was already complete (ARME1: d. 1042. 1. 10-15). According to the questionnaire, the ethnographers' tasks were: to collect material for a historical reference about enterprises; to reveal the significance of the plant (factory) in the life of the district, city, country; to characterize the conditions and organization of labor, a recruitment of workers, a role of Stakhanovites, shock-workers, innovators and hereditary workers in production; to describe the organization of treatment and recreation of workers, cultural work, political life of enterprises and social life of workers; to study the family life of workers including home environment, a family's composition, relationships in families, budget of families, parenting, festive rituals, food and clothing.

The ethnographic specificity of the program was manifested in the need to study interethnic relations. It was necessary to describe the national composition of workers and the relations between workers of different nationalities in prerevolutionary and Soviet times. It was especially important to reveal the topic of "friendly assistance" from the Russian working class to national working cadres (transfer of experience of advanced enterprises, business trips of workers to the center, etc.) (Ibid.: 1. 11). Such a formulation of the question already presupposed "friendship between nations" and harmonious interaction of workers of different nationalities, i.e. the ideology of equality of peoples in the era of socialism. According to Milstein, ethnographers also had to look for elements of national culture in the conservative sphere of "family life": in interior decoration, festive culture, religious remnants, oral folk art, food and clothing (Ibid.: 1. 14). At this point in the questionnaire, it was probably possible to raise the question of cultural ties with peasants. But the peasantry is essentially mentioned only once in the questionnaire (in the question of collective farms as a likely source of recruitment of workers), i.e. it appears as a supplier of personnel and is displaced into the sphere of the biographical past of workers (Ibid.: 1. 11).

In his report, Milstein argued that the study of the workers should have begun with the Russians "as the leading nation among nations of the USSR" (ARME1: d. 1046. 1. 12). The 
Soviet ideology in line with "Russocentrism" (Branderberger 2017) confirmed that all the "national squads of a proletariat arose thanks to the fraternal help" of Russian workers. So, the monolinear class analysis that exalts the workers was used to construct a temporal hierarchy of the Soviet peoples "inside" their equality in the period of socialism. The "Friendship of nations" presupposed class solidarity of workers of all nationalities and a joint struggle against tsarism with the leading position of the Russian people, who within the framework of this ideology was no longer a colonizer, as in the 1920s, but as of the revolutionary proletariat and its party vanguard the main fighter against colonialism. Accordingly, the museum had to display Russian workers, which preceded the demonstration of workers of other Soviet nations in terms of placing and occupied by showpieces space.

To display the Russian people according to the 1950 plan, the entire right wing of the first floor was allocated as a quarter of the entire exhibition area of the museum. All the other nations of the RSFSR should be demonstrated in the same part of the building on the second floor. Such an arrangement of exhibitions, according to the director, would give a correct understanding of "the role of the Russian people, around which the multinational state of the USSR was created" (ARME1: d. 1046. 1. 13). This important task required the involvement of the best forces of the museum. The Department of Russian Ethnography was weakened in personnel terms after the end of the Great Patriotic War, so its employees mainly engaged in the preparation of the pre-revolutionary part of the exhibition and the contemporary collective farm peasantry. The expeditions to the Russian workers were led by experienced employees of other departments: A.S. Bezhkovich (researcher, head of the Department of Ethnography of the peoples of Ukraine and Belarus), E.N. Studenetskaia (head of the Department of Ethnography of the peoples of the Caucasus), P.I. Karalkin (head of the Department of Ethnography of Siberia and the Far East). Five expeditions took place total in 1951-1955, in which Grozny oil workers, Ivanovo textile workers, workers of Rostov "Rostselmash", Nizhny Novgorod "Krasny Sormov" and the Stalinsk "Kuznetsk Metallurgical Combine" (it is now the city of Novokuznetsk) were studied (ARME2: d. 225. 1. 6).

These expeditions differed favorably from the research of industry of the 1930s. They were entirely devoted to the study of workers and lasted, as a rule, about a month. According to the results of the fieldwork, scientific reports were written in the size from 20 to 100 pages. Despite the efforts invested, none of the researchers who went on expeditions to the workers did further specialize in this subject. The sphere of scientific interests of the ethnographers of the SME included historical subjects, cultural "archaisms" and remnants of precapitalist formations, while the academic value of studying workers remained unclear.

It was 1951, when the first museum expedition was organized to the workers at the "Rostselmash" plant. A.S. Bezhkovich (1890-1977), a specialist in Ukrainian and Central Asian ethnography, was sent to the expedition. "Rostselmash" was built on the site near Rostov-on-Don and started in 1929. The choice of the workers of this plant as an object of study was explained by the fact that it was the largest plant in the USSR, providing collective farms and state farms with the advanced agricultural machinery (ARME2: d. 183.1. 2-3). Bezhkovich built his study of the workers of "Rostselmash", largely focusing on classical peasant ethnography. This led him to the conclusion that "the working class, especially persons living in large cities, has already completely lost its ethnographic features and has joined the urban more cultural life" (Ibid.: 1. 70). The workers under study did not save "ethnographic elements neither in occupations, nor in clothing, nor in housing, nor in home furnishings and utensils, as well as in other matters of everyday life" (Ibid.). The workers' clothing is an ordinary city suit, the furniture is factory - made, there is no characteristic type of housing, the rural family life and rituals are also lost. Bezhkovich considered the study of workers' culture to be the way out of this situation. He researched the culture of work (socialist competition, innovation implementation, the Stakhanov movement, etc.), mass rest, sports and physical culture, education and health improvement of children, amateur art activities, large-circulation and wall newspapers. Bezhkovich described all these 
elements of culture in detail as components of the new socialist culture. The task of the ethnographer in the study of workers, in his opinion, was propaganda: he should use the press and exhibitions to share the achievements of the studied plant with the workers of other cities of the USSR and "countries of people's democracy" (Ibid.: 1. 71).

The connection between the factory and the collective farm at Bezhkovich is determined not by the commonality of cultural background, but by the economic relations between the manufacturer and the consumer of agricultural machinery. He considered the search for elements of traditional rural culture among the workers to be a false path. Bezhkovich saw a dangerous temptation for an ethnographer in the workers of "small enterprises located far from large cities" and therefore saved ethnographic features (Ibid.: 1. 69-70). In accordance with the principles of socialist realism (Haber 2014; Petriashin 2018), the object of study and representation should have been only "a large and advanced enterprise, since it is a more correct indicator of the culture of the Soviet worker" (ARME2: d. 183.1. 69-70).

The task stated by Bezhkovich, which consisted in promoting factory achievements and a new culture, assumed allochronism and a temporal break with "backwardness" in the form of the peasant past of workers and contemporary collective farmers. The meaning of discursive placement of collective farmers in cultural backwardness, however, was not in the justification of reforms and paternalistic assistance to "backward" peasants from the state (Ssorin-Chaikov 2003: 81-92), but in the regard of the Russian workers as an "advanced" class as an agent of progress, capable of helping other, less developed classes and peoples. In this construction, the workers produce the latest modernity, which is then "presented" by the proletarian state, including in the form of ethnographic texts and exhibitions, to people, which "need" it in anticipation of gratitude and loyalty (Ssorin-Chaikov 2017: 95-119). Due to the lack of "national specifics" among modern Russian workers, Bezhkovich defined their culture as socialist or Soviet. Other museum employees mostly shared Bezhkovich's point of view. Thus, in the methodological work on the principles of the expedition collection of exhibits (1952), A. Ia. Duisburg wrote: "among the working class, the features of national life are being erased and hence they are not of special scientific interest" (ARME2: d. 192. 1. 5). This did not apply only to Soviet workers. According to Duisburg, the ethnographic museum should show the pre-revolutionary proletariat only as the "driving force of the revolution": their split off from the peasants, difficult living conditions, exploitation and poverty are the reasons for the revolutionary mood.

In 1952, a thematic plan of the exposition on the Russian people was prepared and in the same year it was submitted for discussion with the involvement of specialists from the Leningrad branch of the Institute of Ethnography (among them - T.V. Staniukovich, E.E. Blomqvist, S.M. Abramzon, M.D. Toren). According to the plan, the exposition was to be located in seven halls of the left wing of the first floor (ARME1: d. 1099. 1. 5-6). The first hall was dedicated to the main occupations of the peasants before the revolution (farming, cattle breeding, hunting, etc.). The second hall was intended to demonstrate the culture and everyday life of the peasants (housing, clothing, family relations, utensils, etc.). The third hall was supposed to reveal the theme of folk art, and the fourth -culture and the life of the working class under capitalism. Finally, the fifth hall served as an introduction to the next, Soviet, section and told about the revolutionary movement. The sixth hall was dedicated to showing the life and culture of the modern working class. In the seventh and final hall, ethnographers were going to demonstrate the collective farm peasantry, the flourishing of folk art, the construction sites of communism and so on.

At the meeting, the section on contemporaneity caused the greatest criticism, especially the intention of the SME employees to comprehensively show a working life. The staff of the Institute of Ethnography believed that it was difficult or even impossible to present the culture of the entire Russian people and the "essence of modern life" at the exhibition (Ibid.: 1. 7). The main recommendation was to exclude the working subject and 
show contemporaneity on the material of the collective farm peasantry. Staniukovich suggested that instead of working life, small stands about modern industry should be exhibited, and the main emphasis should be "on the influence of the Russian people on the peoples of the Soviet Union and the international significance of Russia, in particular the RSFSR" (Ibid.: 1. 38). It can be said that she called for a return to the principles of industry representation typical of the SME of the 1930s. The museum staff in justification referred to the resolution of the Ethnographic Meeting of 1951 and to the opinion of the officials which supervised the museum and its exhibitions: they "always put the question before us: why do you show people so limited as only the peasantry? We must show the working class and the Russian people as a whole" (Ibid.: 1. 39).

The answer to the critics of V.I. Gerasimova who was the head of the Russian department revealed the idea of the expositionists from a new side:

We are aware in advance that it may not be possible to show the specifics of the contemporary working class, since we are approaching communism and the lines between national characteristics are blurred. $<\ldots>$ We want to show contemporary Soviet culture, even if it is identical for working Georgians, Tajiks, Russians. We will show the elements of the developing leading Soviet culture. $\langle\ldots\rangle$ We are not afraid that we will see the same elements of furniture there as in the apartments and other workers. We are consciously doing this in order to show the development of Soviet culture as a whole (Ibid.: 1. 9-10).

In other words, the section about contemporary working life was conceived as a representation not only of the culture of the leading class of the Russian people, but also of contemporary Soviet culture. Due to the declared lack of ethnic particularities, Russian workers were historically closest to communism and were able to represent all the peoples of the USSR as a whole.

So, in the discourse of the staff of the ethnographic museum as in Milstein's program statements, in Bezhkovich's scientific report and in the exposition plan of 1952 the ethnography of workers was shaped in the perspective of a monolinear class analysis and included class allochronism (opposition to peasants) and the equality of peoples in the era of socialism. Ethnographers could not but agree with the ideological theses about the "advanced" position of the workers in relation to the peasants and reproduced them in their research and exhibition projects. The presence of elements of peasant culture as signs of "backwardness" among modern workers was practically denied. As a result, the staff of the SME saw only propaganda value in the study of workers and denied him scientific status. Also in the plan of the 1952 exposition, the materials devoted to workers and peasants were divided into different halls, the order of which (from peasants to workers) also reflected their temporal hierarchy. At the same time, in the context of national policy, the culture of workers was presented as socialistic and uniting different peoples of the USSR. The display of this common culture on the example of Russians highlighted their special status in the Soviet "family of peoples". The Russian workers were the most "advanced" workers as the vanguard of the world proletariat and the basis of socialist culture. The ethnography of Russian workers in this perspective was supposed to testify to the fact that the USSR was at the forefront of historical progress and strengthen the country's authority abroad.

\section{Ethnography of workers in 1954-1960: convergence of classes}

Soviet ethnographers generally succumbed to the temptation about which Bezhkovich wrote, and in their research they began to look for peasant and ethnically specific elements in the culture of workers. The historian A.I. Zalessky in his review article criticized ethnographers for arbitrarily dividing the complex but integral life of contemporary workers into "ethnographic" and "non-ethnographic" (Zalessky 1955: 129). The second one was left to historians as an action on will. For example, according to Zalessky the ethnographer 
A.I. Robakidze in his study of Chiatura miners in Georgia "does not so much show the actual working life as he finds similarities between the working life and the peasant life" (Ibid.). When describing the dwelling, he paid special attention to individual houses of workers which saved the traditional rural appearance, and limited himself to one phrase about a new apartment building. This approach no longer presupposed a pronounced class allochronism between workers and peasants. By the mid-1950s, the ethnography of workers in the SME took similar forms.

In the autumn of 1954, ethnographers E.N. Studenetskaia and S.A. Pavlotskaia together with the sculptor M.K. Grigoriev went to investigate the textile workers of Ivanovo and the workers of "Krasnoye Sormovo " (Nizhny Novgorod). The materials of this last major expedition to the workers formed the basis of the first post-war exhibition on the ethnography of the Russian people. Let us dwell in more detail on the workers of the "Krasnoye Sormovo". This plant was a leader in its industry (shipbuilding) and had a hundred-year history (founded in 1849). It is not surprising that Studenetskaia and Pavlotskaia focused their research on pre-revolutionary history. Among their informants was dominated by "old production workers with experience of 30 to 60 years" (ARME2: 214. L. 3). The main topic of interviewing was the genealogy and personal history: "Around this rod is easily going all the major interested in issues of material and non-material culture, working conditions, etc." (ibid: p. 4).

Soon anthropologists had found that in the past the bulk of the Sormovo's collective was made up of peasants from the surrounding villages. As a rule, a construction of ships was laid in the fall and launched in the spring, and in the summer during a field work season a person could labor on his farm. The workers, with whom Studenetskaia and Pavlotskaia talked also wore some notions on agriculture. In their home nutrition, a significant share was made up of products from their own vegetable gardens and orchards. Ethnographers noted how they were " proudly treated to tomatoes and jam from berries collected from the garden" (Ibid.: 1. 52). Some workers even kept cows, for which the plant's management allocated meadows and purchased concentrated feed. For this the workers supplied milk for factory hospitals, daycares and nurseries. Elements of rural culture were also traced in the homes of Sormovo workers. Even in the 1950s, individual wooden houses with rich carvings prevailed among them. In this topic, in the words of Studenetskaia and Pavlotskaia, "it is difficult to distinguish the old from the new" because in the house of the XIX century "a new Soviet man lives now, a worker of one of the largest factories in the country" (Ibid.: 1 . 40). Individual houses under construction largely inherited the pre-revolutionary ones; new apartment buildings typical of large cities embodied the break with the past (Ibid.: 1. 42).

There was in other areas of life less continuity. So, in clothing and home interior, workers adopted urban fashion already at the end of the XIX century. (Ibid.: 1. 30). But the ethnographer's eye caught remnants of the peasant past in the Soviet present: for example, the female habit of not removing the headscarf indoors was seen as such a relic. Studenetskaia and Pavlotskaia found different forms of mixing of pre-revolutionary rural and urban cultures in ritual, religion, and family relations. In the past, there were also separate "hotbeds of high culture" as revolutionary circles, a library, amateur theatrical activities of workers. The real wealth of culture became available, of course, only in Soviet times (libraries, clubs, the Palace of Culture, etc.) (Ibid.: 1. 84). Contemporary culture was revealed by ethnographers on the examples of industrial life (shower rooms, canteens, etc.), attitudes to work (social competitions, innovators, front-rank workers, etc.), education of young people in a boarding school, libraries and bookstores, a factory newspaper and amateur art.

So, the history of the culture of the working class in the description of Studenetskaia and Pavlotskaia is located between the poles of peasant and urban ("petty bourgeois" or intellectual) culture. The study of the pre-revolutionary past and the rural roots of the workers, in their opinion, allowed them to "look for explanations for certain phenomena of the life or culture of the workers, which we observe" (Ibid.: L. 5). If the drawing of a rigid 
boundary between classes in Bezhkovich's writings can be defined as a discrete type of monolinear class analysis, then the consistent underlining by Studenetskaia and Pavlotskaia continuity in the everyday life and economy of workers in relation to peasants can be called its continuous type. In their scientific report, class allochronism, even in a weakened form, is still present. It should also be noted that due to the strengthened connection with the peasantry, the ethnography of the workers has acquired a scientific status in the academic environment.

The program of studying and representing Russian workers of the first half of the 1950s (with a division into life "before" and "after" the revolution) it has never received an exposition embodiment. In 1956, in the wake of "the Thaw", a new General Plan was adopted in the SME. According to its principles "the Soviet period in the life of the peoples of the USSR is shown not separately for each people (in the form of separate endings in each exposition of the museum), but united for all peoples in specially designated halls" (Kriukova, Studenetskaia 1971: 70). Within the framework of this program, the following expositions were opened: "The Art of the peoples of the RSFSR" (1957), "The Art of the Union Republics" (1960), "The USSR as a fraternal union of equal peoples" (1964), "Contemporary folk art of the USSR" (1966), "New and traditional in contemporary folk housing and clothing" (1972), "Contemporary rituals and holidays of the peoples of the USSR" (1988). These exhibitions can be considered, on the one hand, as "an attempt to talk about metaethnic communities in ethnography $<\ldots>$ and the areas of saving ethnic specifics in the culture of an ethnic group" (Dmitriev 2012: 16) and, on the other hand, as a form of ideological legitimization and essentialization of the "Soviet people" (Baranov 2011: 419). The museum representation of the Soviet people as a product of the rapprochement of nations and classes within the framework of the "new historical community" was a form of demonstration of "friendship and equality of peoples" under socialism (Varnavsky 2004). The emphasis in the exposition of contemporaneity was placed on the unity-in-diversity of national cultures, while the issue of "erasing" boundaries between the city and the countryside took the place of problem of class differences. There was a kind of rollback to the principles of expositions of the 1930s: the museum staff replaced the display of contemporary working everyday life with the reflection of achievements in different industries. In particular, at the exhibition "USSR as fraternal Union of equal peoples", industrial issues were addressed through the following topics: "The most important construction projects of the Seven-year plan [Semiletka]", "Planning and electrification"," Automation and people", "Transport" (ARME1: d. 1460. 1. 43). The ethnography of workers and class analysis were displaced to the exhibitions of the pre-revolutionary period.

According to the General Plan of 1956, exhibitions on peoples, in addition to showing traditional rural or nomadic culture, were supposed to demonstrate the life and culture of workers at the turn of the XIX-XX century. It was also important to reveal the themes of "progressive influence of the Russian people" and the mutual influence of peoples as prerequisites for "friendship and equality of nations" in the era of socialism (Kriukova, Studenetskaia 1971: 72). According to these principles, the expositions "Russians" (19571960), "Ukrainians" (1960), "Kazakhs" (1960), "Georgians" (1962) were opened. We can agree with D.A. Baranov (2011: 424-425), that the removal of Soviet sections from the expositions led to the fact that the shown cultures began to look more exotic and archaic. The inclusion of the proletariat in the exhibition narrative was probably supposed to compensate for this effect.

When developing the plan of the Russian exposition, it was decided to show workers and peasants together, "reflecting the continuity of the historical process and comparing the material within each section of the exposition" (Kriukova, Studenetskaia 1971: 74). The exhibition occupied the first floor of the left wing and included five halls. Each hall, with the exception of the first ("Occupations of peasants"), began with a detailed exposition of peasant culture and ended with a more modest representation of working life. The connection 
between the two parts was emphasized by the demonstration of exhibits showing the continuity of the culture of workers and peasants. So, the second hall revealed the evolution of the peasant, who, while engaged in crafts far from home and home crafts, gradually joined the ranks of the industrial proletariat. The labour conditions of the workers were also shown here, including with the help of the layouts described at the beginning of the article. In the third hall, dedicated to housing and household life, the connection with the peasants was demonstrated by the example of the interior "The Room of a textile worker", in which "household items and peasant-type utensils were used along with city purchased utensils" (Guidebook 1961: 43). The fourth hall wore the evolution of the working costume from peasant to urban (by the end of the XIX century). For example, the suit of the wife of the Sormovo's master illustrated the thesis that peasant clothing existed for the longest time among old believers workers (Ibid: 57). The fifth hall, dedicated to non-material culture, passed from folk art, rituals and festive traditions of peasants to the entertainment of workers as participation in folk festivals, visiting "people's houses" and amateur performances. The last subsection was "The formation of the revolutionary consciousness of workers and peasants", this was represented mainly by the example of workers. The topic based on materials about evening courses, Sunday schools, public libraries and working circles. The final element of the entire exhibition was the carved panel "The Victorious People", praising the October Revolution (Ibid: 91).

The exposition "Russians" of 1957-1960 in its principles continued the line of a monolinear class analysis in its continual form, stated even in the scientific report of Studenetskaia and Pavlotskaia about the expedition to Sormovo ${ }^{6}$. The temporal hierarchy between classes has been smoothed out, but it has not completely disappeared. In many topics, the curators tried to show class antagonism, the oppression of peasants and workers by the "kulaks" and capitalists, but the general structure of the exhibition was built on the separation of two related classes within the people's mass. Accordingly, each hall, despite the general chronological framework, acquired a special internal temporality, the historical transformation of peasants into workers: under the conditions of capitalism, some of the peasants were reborn into the proletariat, assimilated progressive urban culture, gained revolutionary consciousness and overthrew tsarism. At the same time, other peasants remained rural inhabitants and missed the "locomotive of history", which carried the workers forward to revolutionary achievements.

$* \quad * \quad *$

The Soviet ethnography of workers can be considered one of the first attempts in world anthropology to radically break with the usual construction of the subject of research with the help of subject - object allocronism, but the temporal hierarchy was left and transferred to the relations between the objects of ethnographic study as the classes of workers and peasants.

This class allochronism was initially embedded in Marxism and Soviet ideology, but it was finally established in political practice during the collectivization and industrialization of the turn of the 1920s and 1930s. In this process, the working class was assigned both the symbolic role of the collective sovereign (the ideologeme of the "dictatorship of the proletariat ") and the role of the real leader of the collectivization in the movement of "twenty-five-thousanders" 7 . But already in the ideology of the mid-1930s, the class struggle was replaced by the convergence of classes under socialism and a monolinear class analysis emerged. The ideo-

\footnotetext{
${ }^{6}$ Russian exposition of 1957-1960 was worked out by Studenetskaia and Pavlotskaia together with other colleagues under the guidance of the head of the Russian department V.I. Gerasimova.

7 "Twenty-five-thousanders" were the advanced workers of large industrial centers, who were appointed by the Communist Party to lead collective and state farms during the period of collectivization.
} 
logical significance of the workers has steadily declined since the mid-1930s (Nikandrov 2018). In the Constitution of 1936, the classes of Soviet society merged into the general category of "working people". The excessive fascination with class analysis on the example of Marrism was condemned by Stalin in the article "Marxism and Problems of Linguistics". In the draft Program of the CPSU (b) of 1947, the Soviet leadership left the dictatorship of the proletariat in the past, and redefined the state of the socialist era as "nationwide". At the XXII Congress of the CPSU (1961), this draft was adopted with some changes. At the same time, Khrushchev proclaimed the Soviet people a new sovereign.

The ideological inflation of workers and class rhetoric allows us to explain why in the second half of the 1930s, the employees of the SME (in a rather modest way) were engaged in research on industry and not workers. Only the aggressive ideological campaigns of the late 1940s, which forced ethnographers to seek protection in a monolinear class analysis, and strong socio-economic shifts (urbanization, industrialization) for some time reversed the general trend. The subsequent history of the decline of the ethnography of workers reflects the marked ideological inflation. If in the early 1950s ethnographers strictly separated workers from peasants, then during the "Thaw" the class partitions began to go out, and researchers began to describe the continuity and commonality of their life and culture. The discrete type of monolinear class analysis had been replaced by a continuous one.

By the beginning of the 1960s, the ethnography of workers in the SME was no longer relevant when exhibiting contemporaneity, but it retained its significance when showing the life of nations before the Revolution. Finally, in the Russian people display of the 1980s and 1990s, the exhibition space of the workers was reduced to the area of a wall of one hall. In the Era of Stagnation, researchers lost interest in the ethnography of workers, and it transformed to the ethnography of the city, in which the subject of research was shaped according to other principles (Budina, Shmeleva 1977; Sokolovsky 2014; Wiener, Divisenko 2018).

\section{Acknowledgments}

The author thanks S.S. Alymov, M.M. Prokhortsova, M.R. Tereshin, anonymous reviewers and all participants of the "anthropological circle" under the leadership of N.V. Ssorin-Chaikov for their comments on the text.

\section{References}

Abashin, S. 2011. Ethnographic Views of Socialist Reforms in Soviet Central Asia: Collective Farm (Kolkhoz) Monographs. In Exploring the Edge of Empire: Soviet Era Anthropology in the Caucasus and Central Asia, edited by F. Mühlfried and S. Sokolovskiy, 83-98. Berlin: Lit-Verlag.

Alymov, S. 2009. Kosmopolitizm, marrizm i prochie "grekhi": otechestvennye etnografy i arkheologi na rubezhe 1940-1950-kh godov [Cosmopolitism, Marrism and Other "Sins": Soviet Ethnographers and Archeologists in Late 1940s - Early 1950s]. Novoe literaturnoe obozrenie 3 (97): 7-36.

Alymov, S. 2010. Nesluchainoe selo: sovetskie etnografy i kolkhozniki na puti "ot starogo k novomu" i obratno [The Nonrandom Village: Soviet Ethnographers and Collective Farmers on the Way "from Old to New" and Back]. Novoe literaturnoe obozrenie 1 (101): 109-129.

Alymov, S. 2014. Ethnography, Marxism and Soviet Ideology. In An Empire of Others, edited by R. Cvetkovski and A. Hofmeister, 121-144. Budapest: CEU Press.

Arziutov, D.V., S.S. Alymov, and D.G. Anderson, eds. 2014. Ot klassikov k marksizmu: soveshchanie etnografov Moskvy i Leningrada (5-11 aprelia 1929 g.) [From Classics to Marxism: The Meeting of Ethnographers from Moscow and Leningrad (5-11 April 1929)]. St. Petersburg: MAE RAN.

Astapovich, Z.A., and K.V. Gusev, eds. 1962. Razvitie rabochego klassa v natsional'nykh respublikakh SSSR [Development of the Working Class in the National Republics of the USSR]. Moscow: Izdatel'stvo VPG i AON pri TsK KPSS, 1962.

Baranov, D.A. 2011. Obraz sovetskogo naroda v reprezentativnykh praktikakh Gosudarstvennogo muzeia etnografii narodov SSSR vo vtoroi polovine XX v. [Soviet People's Image in Representational Practices of the State Museum of Ethnography of USSR People in Second Half 
of XX ${ }^{\text {th }}$ Century]. In Antropologiia sotsial'nykh peremen. Issledovaniia po sotsial'no-kul'turnoi antropologii [Anthropology of Social Changes: Studies in Social-Cultural Anthropology], edited by E. Guchinova and H. Komarova, 414-428. Moscow: ROSSPEN.

Baranov, D.A. 2012. "Priruchenie" traditsii: vkliuchenie poniatiia traditsii v narrativ o sovetskom narode (po materialam GME narodov SSSR) [The "Taming" of Tradition: The Inclusion of the Concept of Tradition into the Narrative of the Soviet People (Based on the State Ethnographic Museum of the Peoples of the USSR)]. Antropologicheskii forum 16: 351-366.

Bevernage, B. 2016. Tales of Pastness and Contemporaneity: On the Politics of Time in History and Anthropology. Rethinking History: The Journal of Theory and Practice 20 (3): 352-374.

Birth, K. 2008. The Creation of Coevalness and the Danger of Homochronism. Journal of the Royal Anthropological Institute 14 (1): 3-20.

Branderberger, D. 2017. Stalinskii russotsentrizm. Sovetskaia massovaia kul'tura i formirovanie russkogo natsional'nogo samosoznaniia (1931-1956) [Stalin's Russocentrism: Soviet Mass Culture and the Formation of Russian National Identity (1931-1956)]. Moscow: Politicheskaia entsiklopediia, 2017.

Budina, O.R., and M.N. Shmeleva. 1977. Etnograficheskoe izuchenie goroda v SSSR [Ethnographic Study of the City in the USSR]. Sovetskaia etnografiia 6: 21-31.

Chakrabarty, D. 2000. Provincializing Europe: Postcolonial Thought and Historical Difference. Princeton: Princeton University Press.

Dmitriev, V.A. 2012. Gosudarstvennyi muzei etnografii - svoi put' mezhdu ideologiei i naukoi [State Museum of Ethnography: Steering an Independent Course between Ideology and Knowledge]. Muzei, traditsii, etnichnost' 2: 6-20.

Dolgova, E.A. 2018. O biografii odnogo stalinskogo upravlentsa: Efim Abramovich Mil'shtein [One Biography of the Stalinist Manager: Efim Abramovich Mil'shtein]. Noveishaia istoriia Rossii 4: 912-924.

Etkind, A. 2011. Internal Colonization: Russia's Imperial Experience. Cambridge: Polity Press.

Etkind, A., D. Uffel'man, and I. Kukulin, eds. 2012. Tam, vnutri. Praktiki vnutrennei kolonizatsii v kul'turnoi istorii Rossii [There, Inside: Practices of Internal Colonization in Russian Cultural History]. Moscow: Novoe literaturnoe obozrenie.

Fabian, J. 1983. Time and the Other. How Anthropology Makes its Object. New York: Columbia University Press.

Gouldner, A.W. 1977-78. Stalinism: A Study of Internal Colonialism. Telos 34: 5-48.

Grinkova, N.P. 1947. Obriad "vozhdeniia rusalki" v sele B. Vereika Voronezhskoi oblasti [Ritual of "Leading the Mermaid" in B. Vereika Village, Voronezh Oblast]. Sovetskaia etnografiia 1: $178-184$.

Haber, M. 2014. The Soviet Ethnographers as a Social Engineer: Socialist Realism and the Study of Rural Life, 1945-1958. The Soviet and Post-Soviet Review 41 (2): 194-219.

Hirsch, F. 2005. Empire of Nations: Ethnographic Knowledge and the Making of the Soviet Union. Ithaca: Cornell University Press.

Korbe, O. 1950. Sessiia Uchenogo soveta Instituta etnografii, posviashchennaia itogam ekspeditsionnykh issledovanii $1949 \mathrm{~g}$. [Session of the Academic Council of the Institute of Ethnography, Dedicated to the Results of Expeditionary Researches in 1949]. Sovetskaia etnografiia 3: 183-186.

Kriukova, T.A. 1947. "Vozhdenie rusalki" v sele Os'kine Voronezhskoi oblasti (po materialam ekspeditsii Gosudarstvennogo muzeia etnografii 1936 g.) [“Leading the Mermaid” in Os'kino village, Voronezh Oblast (Based on Expedition Materials of State Museum of Ethnography from 1936)]. Sovetskaia etnografiia 1: 185-192.

Kriukova, T.A., and E.N. Studenetskaia. 1971. Gosudarstvennyi muzei etnografii narodov SSSR za piat'desiat let sovetskoi vlasti [The State Museum of Ethnography of USSR Peoples for 50 Years of Soviet Authority]. In Ocherki istorii muzeinogo dela v SSSR [Essays on History of Museum Work in USSR], edited by A.B. Zaks, 7: 9-120. Moscow: Sovetskaia Rossiia.

Malinovskaia, Z. 1932. Nauchnye komandirovki Etnograficheskogo otdela Gos. Russkogo muzeia v 1932 g. v Leningradskuiu oblast' [Scientific Expeditions of the Ethnographic Department of the State Russian Museum in 1932 in Leningrad Province]. Sovetskaia etnografiia 5-6: 232-234.

Milonov, Yu. 1930. Tselevye ustanovki muzeev razlichnogo tipa [Telic Policy of Different Types of Museums]. In Pervyi Vserossiiskii muzeinyi s'ezd: tezisy dokladov [The First All-Russian Museum Congress: Theses of the Report], 3-11. Moscow; Leningrad: OGIZ. 
Mitrofanova, A.V. 1964. Razvitie rabochego klassa SSSR v period zaversheniia stroitel'stva sotsializma i postepennogo perekhoda k kommunizmu (1936-1961 gg.) [Development of Working Class of USSR During the Completion of the Construction of Socialism and the Gradual Transition to Communism]. In Formirovanie i razvitie sovetskogo rabochego klassa (1917-1961 gg.) [Formation and Development of Soviet Working Class (1917-1961)], edited by R.P. Dadykin, 55-71. Moscow: Nauka.

Morfino, V., and P.D. Thomas, eds. 2018. The Government of Time: Theories of Plural Temporality in the Marxist Tradition. Leiden: Brill.

Nikandrov, A.V. 2018. Ot diktatury proletariata k obshchenarodnomu gosudarstvu: "likvidatsiia dogmatizma" ili revizionizm? [From the Proletariat Dictatorship to the Nationwide State: The "Elimination of Dogmatism" or Revisionism?]. Filosofiia i obshchestvo 1: 18-36.

Novozhilov, A.G. 2012. Etnograficheskoe izuchenie kolkhoznogo krest'ianstva v 1930-1950-kh godakh [Ethnographic Research of Collective Farmers in 1930s-1950s]. Vestnik SPbGU, Seriia 2: Istoriia 2: 90-101.

Petriashin, S. 2018. Sotsrealizm i etnografiia: izuchenie i reprezentatsiia sovetskoi sovremennosti v etnograficheskom muzee 1930-kh gg. [Socialist Realism and Ethnography: The Study and Representation of Soviet Contemporaneity in Ethnographic Museums in the 1930s]. Antropologicheskii forum 39: 143-175.

Slezkine, Y. 1991. The Fall of Soviet Ethnography, 1928-38. Current Anthropology 32 (4): 476-484.

Slezkine, Y. 1994. Arctic Mirrors: Russia and the Small Peoples of the North. Ithaca: Cornell University Press.

Solovei, T.D. 1998. Ot "burzhuaznoi" etnologii k "sovetskoi" etnografii: istoriia otechestvennoi etnologii pervoi treti XX veka [From "Bourgeois" Ethnology to "Soviet" Ethnography: History of Russian Ethnology of the First Third of $\left.X^{\text {th }}\right]$. Moscow: IEA RAN.

Sokolovskiy, S.V. 2014. Gorodskaia povsednevnost', subkul'tury i rossiiskaia gorodskaia etnografiia [Urban Everyday Life, Subcultures and Russian Urban Ethnography]. In Etnometodologiia: problemy, podkhody, kontseptsii [Ethnomethodology: Problems, Approaches, Conceptions], edited by A.A. Piskoppel, V.R. Rokitianskii, and L.P. Shchedrovitskii, 18: 122-143. Moscow: Nasledie MMK.

Ssorin-Chaikov, N. 2003. The Social Life of the State in Subarctic Siberia. Stanford: Stanford University Press.

Ssorin-Chaikov, N. 2017. Two Lenins: A Brief Anthropology of Time. Chicago: Hau Books.

Timasheff, N.S. 1946. The Great Retreat. New York: E.P. Dutton and Company.

Varnavskii, P.K. 2004. Sovetskii narod: sozdanie edinoi identichnosti v SSSR kak konstruirovanie obshchei pamiati (na materialakh Buriatskoi ASSR) [Soviet People: The Making of a Common Identity in the USSR as the Creation of Common Memory (the Case of Buriat ASSR)]. $A b$ Imperio 4: 239-262.

Verniaev, I.I. 2005. Lokal'nye monograficheskie issledovaniia derevni 1920-1930-kh godov: tseli, metodiki, rezul'taty [Local Monographic Investigations of Village in the 1920s-1930s: Aims, Methods, Results]. In Problemy istoricheskogo regionovedeniia [Problems of Historical Area Studies], edited by Yu.V. Krivosheev, 29-64. St. Petersburg: Izdatelstvo SPbGU, 2005.

Viner, B.E., and K.S. Divisenko. 2018. Stanovlenie etnografii goroda v Leningrade/Peterburge [The Making of Urban Anthropology in Leningrad/St. Petersburg]. Peterburgskaia sotsiologiia segodnia 9: 143-168.

Viola, L. 1996. Peasant Rebels under Stalin: Collectivization and the Culture of Peasant Resistance. New York: Oxford University Press.

Zalesskii, A.I. 1955. Ob izuchenii byta rabochego klassa SSSR [On Study of Everyday Life of USSR Working Class]. Voprosy istorii 5: 128-129.

Zhdanko, T.A. 1951. Rabota Instituta etnografii Akademii nauk SSSR v 1950 g. [The Work of Institute of Ethnography of USSR Academy of Sciences]. Sovetskaia etnografiia 2: 214-219. 